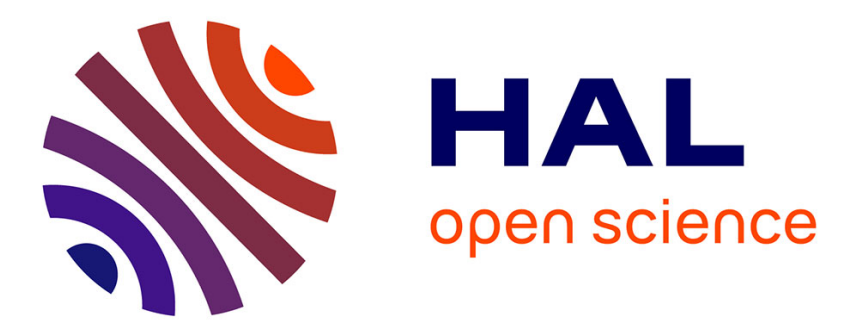

\title{
Improvement of corrosion protection of steel by incorporation of a new phosphonated fatty acid in a phosphorus-containing polymer coating obtained by UV curing
}

France Millet, Rémi Auvergne, Sylvain Caillol, Ghislain David, Abdelatif

Manseri, Nadine Pébère

\section{To cite this version:}

France Millet, Rémi Auvergne, Sylvain Caillol, Ghislain David, Abdelatif Manseri, et al.. Improvement of corrosion protection of steel by incorporation of a new phosphonated fatty acid in a phosphoruscontaining polymer coating obtained by UV curing. Progress in Organic Coatings, 2014, vol. 77 ( ${ }^{\circ}$ 2), pp. 285-291. 10.1016/j.porgcoat.2013.10.002 . hal-01165505

\author{
HAL Id: hal-01165505 \\ https://hal.science/hal-01165505
}

Submitted on 19 Jun 2015

HAL is a multi-disciplinary open access archive for the deposit and dissemination of scientific research documents, whether they are published or not. The documents may come from teaching and research institutions in France or abroad, or from public or private research centers.
L'archive ouverte pluridisciplinaire HAL, est destinée au dépôt et à la diffusion de documents scientifiques de niveau recherche, publiés ou non, émanant des établissements d'enseignement et de recherche français ou étrangers, des laboratoires publics ou privés. 


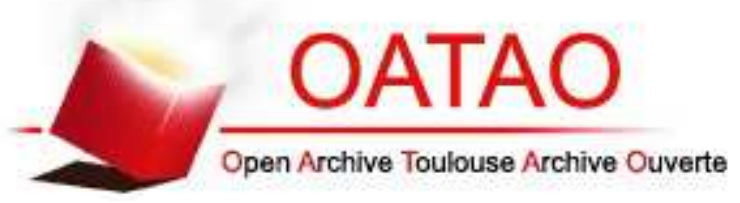

\section{Open Archive TOULOUSE Archive Ouverte (OATAO)}

OATAO is an open access repository that collects the work of Toulouse researchers and makes it freely available over the web where possible.

This is an author-deposited version published in : http://oatao.univ-toulouse.fr/ Eprints ID : 14082

To link to this article : doi: $10.1016 /$ j.porgcoat.2013.10.002

URL : http://dx.doi.org/10.1016/j.porgcoat.2013.10.002

To cite this version : Millet, France and Auvergne, Rémi and Caillol, Sylvain and David, Ghislain and Manseri, Abdelatif and Pébère, Nadine Improvement of corrosion protection of steel by incorporation of a new phosphonated fatty acid in a phosphorus-containing polymer coating obtained by UV curing. (2014) Progress in Organic Coatings, vol. $77\left(\mathrm{n}^{\circ} 2\right)$. pp. 285-291. ISSN 0300-9440

Any correspondance concerning this service should be sent to the repository administrator: staff-oatao@ listes-diff.inp-toulouse.fr 


\title{
Improvement of corrosion protection of steel by incorporation of a new phosphonated fatty acid in a phosphorus-containing polymer coating obtained by UV curing
}

\author{
France Millet $^{\mathrm{a}}$, Rémi Auvergne ${ }^{\mathrm{b}}$, Sylvain Caillol ${ }^{\mathrm{b}}$, Ghislain David ${ }^{\mathrm{b}}$, \\ Abdelatif Manseri ${ }^{\mathrm{b}}$, Nadine Pébère ${ }^{\mathrm{a}, *}$ \\ a Université de Toulouse, CIRIMAT, UPS/INPT/CNRS, ENSIACET, 4 allée Emile Monso BP 44362, 31030 Toulouse Cedex 4, France \\ ${ }^{\mathrm{b}}$ Institut Charles Gerhardt UMR CNRS 5253, Laboratoire Ingénierie et Architecture Macromoléculaire, Ecole Nationale Supérieure de Chimie de Montpellier, \\ 8 rue de l'Ecole Normale, 34296 Montpellier Cedex 05, France
}

Keywords:

Phosphonated methacrylate

Coating

Phosphonated fatty acid

Inhibitor

Electrochemical impedance spectroscopy

\begin{abstract}
A B S T R A C T
Six formulations containing diacrylate monomers (from 89 to $92.5 \%(\mathrm{w} / \mathrm{w})$ ) as well as a phosphonated methacrylate monomer (from 1 to $10 \%(\mathrm{w} / \mathrm{w})$ ) were prepared. All formulations were UV-cured and the corrosion performance of the resulting coatings applied onto a steel substrate was assessed by electrochemical impedance spectroscopy (EIS). It was first shown that the coatings containing phosphonic acid methacrylate (MAPC1 $\left.(\mathrm{OH})_{2}\right)$ instead of methacrylate phosphonic dimethyl ester (MAPC1) presented higher corrosion protection related to the strong adhesive properties of phosphonic acid on the metal substrate. A minimum MAPC1 $(\mathrm{OH})_{2}$ content of $2.5 \%$ was determined to provide the highest impedance values (best efficiency). Then, a new bio-based compound, i.e. phosphonic acid-bearing oleic acid (phosphonated fatty acid), was synthesized and added as an inhibitor to the formulations. In the presence of this compound, the corrosion protection was notably improved. The beneficial effect of phosphonated fatty acid was explained by its inhibitive action at the steel/coating interface and by the improvement of the barrier properties.
\end{abstract}

\section{Introduction}

In recent years, phosphorus-containing products have gained significant development due to their interesting properties in various applications. For example, dental adhesives, ion-exchange resins and adhesion promotors are three of the more common applications [1-7]. Furthermore, flame retardants containing phosphorus atoms progressively came to replace halogenated ones [8-12]. Phosphorus-containing compounds are excellent promotors with respect to adhesion, and thus improve anti-corrosion effects. Commercial anti-corrosion polymers are generally formed from Sipomer ${ }^{\circledR}$ or Phosmer $^{\circledR}$ monomers, which are phosphatetype (meth)acrylates, and can be readily polymerized via emulsion or solution [13,14]. Sheffer et al. [15] reported the enhanced corrosion protection of sol-gel films on aluminum substrate by entrapping phosphonate group in organosilanes. However, phosphonate groups which remain as additives in a physical mixture can lead to dynamic phenomena such as aggregation, phase separation or leaching by solvent or water with time. Such

* Corresponding author. Tel.: +33 534323423.

E-mail address: nadine.pebere@ensiacet.fr (N. Pébère) disadvantages can be overcome if the phosphonates form part of polymer network. Kannan et al. [16,17] reported the synthesis of a highly cross-linked methacrylate-phospho-silicate hybrid by copolymerizing 2-(methacryloyloxy)ethyl phosphate (EGMP), containing a polymerizable methacrylate group and functional phosphate group with 3-[(methacryloyloxy) propyl] trimethoxysilane (MEMO) which possesses a polymerizable methacryloxy group at one end and alkoxy silane groups capable of forming inorganic networks via sol-gel route at the other end. Protection of steel substrates with these hybrid coatings was explained by the strong interfacial acid-base interactions of $\mathrm{P}_{-} \mathrm{O}^{-}$groups from phosphate with the $\mathrm{M}^{n+}$ from the metal substrate [17]. Polymers with some phosphonate functionality have long been established as excellent adhesives and anti-corrosion compounds [18-25]. However, there has been very little investigation into the use of phosphonate-type methacrylates for the same purpose $[13,14,26]$. In an effort to synthetize new types of phosphonated methacrylate monomers, we have proposed a series of monomers with the following general formula: $\mathrm{CH}_{2}=\mathrm{C}\left(\mathrm{CH}_{3}\right) \mathrm{C}(\mathrm{O}) \mathrm{O}\left(\mathrm{CH}_{2}\right)_{n} \mathrm{P}(\mathrm{O})\left(\mathrm{OR}_{1}\right)\left(\mathrm{OR}_{2}\right)$. The synthesis was achieved by using several organic pathways such as the wellknown Arbusov reaction $[27,28]$ or by using hydroxyl-phosphonate compounds under Schotten-Bauman conditions [29] ending with methacrylates bearing spacer $n$ values from 1 to 11 . More 
recently, new $\mathrm{N}, \mathrm{N}$-amino-bisphosphonic-containing methacrylates $\left(\mathrm{MAC}_{n} \mathrm{NP}_{2}\right)$ [30] and new gem-bisphophonic-containing methacrylates $\left(\mathrm{MAC}_{n} \mathrm{P}_{2}\right)$ [31] have also been synthesized and polymerized under UV-light. The resulting coatings, evaluated by salt spray test, showed efficient corrosion protection of steel after over $900 \mathrm{~h}$ of exposure. Posner et al. [32] already reported UV curable coatings based on acrylate/styrene copolymers to be efficient against corrosion, but no phosphonate-containing methacrylate compound has been used so far.

The aim of the present study was to evaluate the corrosion protection of coatings obtained from UV polymerization based on (meth)acrylate compounds and more specifically diacrylate monomers as well as phosphonated methacrylate monomers. The coatings were applied on a steel substrate and the behavior of the steel/coating interface was characterized during immersion in $0.1 \mathrm{M} \mathrm{NaCl}$ by electrochemical impedance spectroscopy [33-37]. In the first part of the study, the influence of the phosphonic acid methacrylate content on the corrosion protection was investigated. Then, in a second step, a new phosphonated fatty acid was synthesized and added to the formulation prior to the UV polymerization. Note that this molecule does not participate in the UV cross-linking with acrylate monomers but was incorporated in the formulation as an inhibitive compound to enhance the corrosion protection of the steel.

\section{Experimental}

\subsection{Materials}

All chemicals were purchased from Aldrich and used without further purification.

Two phosphonated methacrylate monomers MAPC1 and MAPC1 $(\mathrm{OH})_{2}$ were synthesized according to a previously described procedure [26]. Their chemical structure is shown in Fig. 1.

Low-carbon steel Q-Panel plates (SAE1008/1010, R type) $150 \mathrm{~mm} \times 75 \mathrm{~mm} \times 0.8 \mathrm{~mm}$ were used as substrate.

\subsection{Synthesis of a new phosphonated fatty acid (phosphonic acid-bearing oleic acid)}

In a first step, the phosphonation of methyl oleate was carried out in a glass reactor containing $0.249 \mathrm{~g}(0.00170 \mathrm{~mol})$ of di-tertbutyl peroxide, $10 \mathrm{~g}(0.034 \mathrm{~mol})$ of methyl oleate and two molar equivalents of dimethyl phosphite. The mixture was heated to $125^{\circ} \mathrm{C}$ for $12 \mathrm{~h}$. After cooling to room temperature, excess dimethyl phosphite was removed under high vacuum. Phosphonic esterbearing oleic methyl ester was obtained with 78\% yield. This synthesis was performed by Specific Polymers and sold under the SP-3S-10-001 trademark.

${ }^{1} \mathrm{H}$ NMR $\left(\mathrm{CDCl}_{3}, \delta, \mathrm{ppm}\right): 3.70\left(\mathrm{~d}, 6 \mathrm{H}, \mathrm{PO}\left(\mathrm{OCH}_{3}\right)_{2}\right), 3.63(\mathrm{~s}, 3 \mathrm{H}$, $\left.\mathrm{COOCH}_{3}\right), 2.26\left(\mathrm{t}, 2 \mathrm{H}, \mathrm{CH}_{2}-\mathrm{COOCH}_{3}\right), 0.84\left(\mathrm{t}, 3 \mathrm{H}, \mathrm{CH}_{3}-\mathrm{CH}_{2}\right) .{ }^{31} \mathrm{P}$ $\left(\mathrm{CDCl}_{3}, \delta, \mathrm{ppm}\right): 37.7$.

In a second step, $10 \mathrm{~g}(0.025 \mathrm{~mol})$ of phosphonic ester-bearing oleic methyl ester and $50 \mathrm{~g}$ of dioxane were introduced into a single-necked round bottom flask equipped with a condenser<smiles>C=C(C)C(=O)OCP(=O)(OC)OC</smiles>

(a)<smiles>C=C(C)C(=O)OCP(=O)(O)O</smiles>

(b)
Fig. 1. Structures of the monomers: (a) methacrylate phosphonic dimethyl ester (MAPC1) and (b) phosphonic acid methacrylate (MAPC1 $\left.(\mathrm{OH})_{2}\right)$.
Table 1

Composition of the different formulations prepared for the electrochemical characterization. Each formula contains 6\% Darocur.

\begin{tabular}{lllll}
\hline Formulation & $\begin{array}{l}\text { Acrylates } \\
\text { (wt. \%) }\end{array}$ & $\begin{array}{l}\text { MAPC1 (wt. } \\
\%)\end{array}$ & $\begin{array}{l}\text { MAPC1(OH) } \\
\text { (wt. \%) }\end{array}$ & $\begin{array}{l}\text { New phosphonated } \\
\text { fatty acid (wt. \%) }\end{array}$ \\
\hline 1 & 92.7 & 1.3 & - & - \\
2 & 92.7 & - & 1.3 & - \\
3 & 91.5 & - & 2.5 & - \\
4 & 89 & - & 5 & - \\
5 & 84 & - & 10 & - \\
6 & 89 & - & 2.5 & 2.5 \\
\hline
\end{tabular}

and a magnetic stirrer. Subsequently, two molar equivalents of hydrochloric acid were added dropwise. Then, the solution was vigorously stirred under dioxane refluxing for $6 \mathrm{~h}$. After purification, phosphonic acid-bearing oleic acid was obtained with 55\% yield. This synthesis was performed by specific polymers and sold under the SP-3S-10-009 trademark.

${ }^{1} \mathrm{H}$ NMR $\left(\mathrm{CD}_{3} \mathrm{OD}, \delta, \mathrm{ppm}\right): 5.03\left(\mathrm{~s}, 4 \mathrm{H}, \mathrm{PO}(\mathrm{OH})_{2}\right), 2.30(\mathrm{t}, 2 \mathrm{H}$, $\left.\mathrm{CH}_{2}-\mathrm{COOH}\right), 0.92\left(\mathrm{t}, 3 \mathrm{H}, \mathrm{CH}_{3}-\mathrm{CH}_{2}\right) .{ }^{31} \mathrm{P}\left(\mathrm{CD}_{3} \mathrm{OD}, \delta, \mathrm{ppm}\right): 33.2$.

The chemical structure of the products was determined by ${ }^{1} \mathrm{H}$ and ${ }^{31} \mathrm{P}$ NMR (Bruker AC $400 \mathrm{MHz}$ ) at room temperature in $\mathrm{CDCl}_{3}$ solutions. Abbreviations $\mathrm{s}, \mathrm{d}, \mathrm{t}, \mathrm{q}, \mathrm{m}$ stand for singlet, doublet, triplet, quadruplet and multiplet, respectively. The INVGATE procedure with delay D1 of $10 \mathrm{~s}$ was used to quantify the final yield.

\subsection{UV photopolymerization of methacrylate monomers and coating preparation}

The UV polymerization of mixtures of (meth)acrylates (composed of tripropyleneglycol diacrylate, hexanedioldiacrylate and phosphonated methacrylate MAPC1 or MAPC1 $\left.(\mathrm{OH})_{2}\right)$, and Darocur $1173(6 \%, w / w)$ as a photoinitiator was studied by real time FT-IR spectroscopy with a Nicolet Nexus apparatus with $2 \mathrm{~cm}^{-1}$ accuracy using OMNIC software. The UV intensity was measured using a Solatell UV spectroradiometer apparatus (4D Controls Limited, Cornwall, UK). The kinetics of (meth)acrylate monomer conversion have already been published [38]. The reagents were blended without solvent. Six different formulations were prepared. The compositions are indicated in Table 1. The first composition (F1) was composed of acrylates, MAPC1 and photoinitiator, while the four subsequent compositions (F2-F5) contained acrylates and various amounts of the MAPC1 $(\mathrm{OH})_{2}$ with photoinitiator. The last formulation (F6) contained 2.5\% MAPC1 $(\mathrm{OH})_{2}$ as well as $2.5 \%$ new phosphonated fatty acid.

The steel substrates were degreased with methyl ethyl ketone (MEK) and dried in warm air for $30 \mathrm{~min}$. Then, the liquid formulation was uniformly applied on the steel sample to obtain a uniform layer after curing. The films were applied with a SHEEN bar coater. Coated samples were then photopolymerized. The UV source was placed perpendicular to the sample surface and induced the crosslinking reaction, monitored in real-time via FT-IR. Complete conversion of monomer to polymer was obtained after ca. 60 s, confirmed by following the intensity of IR absorption at $812 \mathrm{~cm}^{-1}$ (characteristic of the $\mathrm{C}=\mathrm{C}$ methacrylate monomer double bond). The dry film thickness was $20 \pm 2 \mu \mathrm{m}$ (measured by a Bykotest 7500 digital meter).

\subsection{Electrochemical measurements}

A three-electrode electrochemical cell was used in electrochemical impedance measurements. A coated specimen was used as working electrode. A cylindrical Plexiglas tube was assembled on top of the coated sample (exposed surface area: $29 \mathrm{~cm}^{2}$ ) and 
filled with the aggressive solution prepared from distilled water by adding $0.1 \mathrm{M} \mathrm{NaCl}$ (reagent grade). A large platinum sheet and a saturated calomel electrode were used as counter and reference electrodes, respectively. The electrochemical cell was kept at room temperature and open to air. Electrochemical impedance measurements were carried out using a Solartron 1287 electrochemical interface connected to a Solartron 1250 frequency response analyser. Impedance diagrams were obtained over a frequency range of $65 \mathrm{kHz}$ to a few $\mathrm{mHz}$ with six points per decade using a $20 \mathrm{mV}$ peakto-peak sinusoidal voltage. The linearity of the system was checked by varying the amplitude of the ac signal applied to the sample. The electrochemical behavior of the steel/coatings interface was characterized for different exposure times to the aggressive solution ranging from $2 \mathrm{~h}$ to $72 \mathrm{~h}$ ( 3 days).

\subsection{Scanning electron microscopy (SEM) observations}

SEM, coupled with X-ray diffraction (SEM-EDX), was used to visualize the morphology of the coatings and define localized concentrations of phosphorus. Analyses were performed on crosssections of the coating material. SEM-EDX analyses were performed using a LEO 435VP electron microscope operating at $8 \mathrm{kV}$. The phosphorus profiles were obtained from 64 measurements through the whole coating thickness.

\section{Results and discussion}

Impedance measurements were performed to evaluate the effects of the phosphonated methacrylate monomers on the corrosion protection of the steel coated by the different formulations. First, the influence of the methacrylate monomers (MAPC1 or MAPC1 $\left.(\mathrm{OH})_{2}\right)$ was investigated. Then, the influence of the addition of the new phosphonated fatty acid was studied. It can be mentioned that corrosion appeared relatively rapidly indicating that the coatings offered a low corrosion protection. Albeit unsatisfactory it is helpful to rapidly discriminate the effect of the additives. For this reason, the impedance results were compared for only $24 \mathrm{~h}$ of immersion in the $\mathrm{NaCl}$ solution.

\subsection{The effect of both the nature and the content of the} phosphonated methacrylate monomer (ester or acid groups) on corrosion protection

Fig. 2 reports the impedance diagrams obtained after $24 \mathrm{~h}$ of immersion in the $0.1 \mathrm{M} \mathrm{NaCl}$ solution for the two formulations (F1 and F2). The diagrams are characterized by two time constants: the high-frequency (HF) part of the diagrams (from $10^{5}$ to $1 \mathrm{~Hz}$ ) is related to the coating and attributed to the barrier properties of

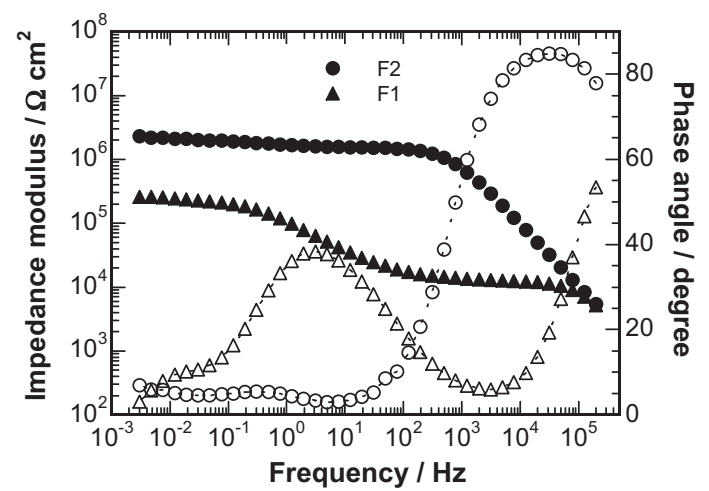

Fig. 2. Electrochemical impedance diagrams (Bode representation) obtained for the $\mathrm{F} 1$ and $\mathrm{F} 2$ samples after $24 \mathrm{~h}$ of immersion in $0.1 \mathrm{M} \mathrm{NaCl}$ solution.

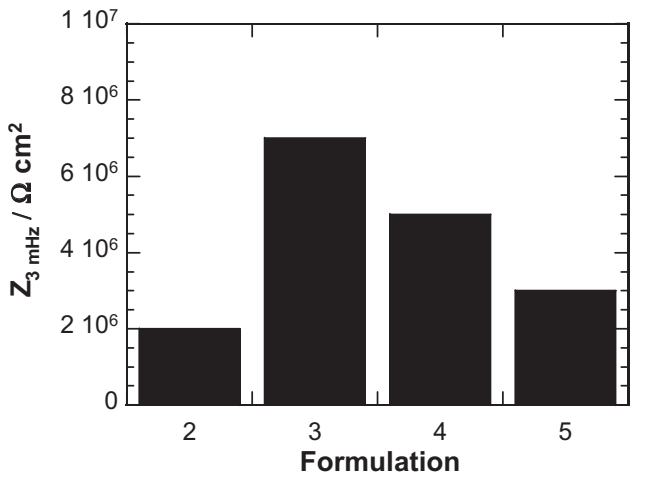

Fig. 3. $|\mathrm{Z}|_{3 \mathrm{mHz}}$ after $24 \mathrm{~h}$ of immersion in $0.1 \mathrm{M} \mathrm{NaCl}$ solution for the formulations with different $\mathrm{MAPC}(\mathrm{OH})_{2}$ concentrations.

the film, while the low-frequency (LF) part (from 1 to $10^{-3} \mathrm{~Hz}$ ) corresponds to the reactions occurring at the metal/coating interface through defects and pores in the coating $[39,40]$. For the F1 coating, the barrier effect (HF range) is significantly lower than for the F2 coating: the impedance value is only $2 \times 10^{4} \Omega \mathrm{cm}^{2}$ (plateau in the $\mathrm{HF}$ range). In addition, the impedance modulus at $3 \mathrm{mHz}$ is low which indicates that the $\mathrm{F} 1$ coating is poorly efficient at protecting the steel surface which is also a consequence of the poor barrier effect. The diagram for the F2 coating reveals a higher impedance modulus in the HF range $\left(2 \times 10^{6} \Omega \mathrm{cm}^{2}\right)$ compared to $\mathrm{F} 1$ indicating that the barrier effect was improved. The barrier effect leads to a decrease of the surface area in contact with the electrolyte (high impedance modulus in the LF range) and as a consequence coating F2 was more protective.

From this first set of experiments, it can be concluded that the coating containing acid methacrylate instead of ester methacrylate conferred a more efficient corrosion protection to the metal substrate. Thus, in the reminder of the study only $\operatorname{MAPC} 1(\mathrm{OH})_{2}$ was used.

The influence of the MAPC1 $(\mathrm{OH})_{2}$ content in the coating for the corrosion protection of the steel was investigated. Similar formulations were prepared and only the MAPC $1(\mathrm{OH})_{2}$ content was changed ( $1 \%, 2.5 \%, 5 \%$ and $10 \%)$. The impedance diagrams presented the same shape and are not reported here. It can be mentioned that the HF part of the impedance diagrams was poorly modified in the presence of different MAPC $1(\mathrm{OH})_{2}$ concentrations and only the LF part changed. This result indicates that MAPC $1(\mathrm{OH})_{2}$ acts mainly at the metal/coating interface. It was proposed by Kittel et al. [41] and the group of Bierwagen [42-44] that the impedance modulus at low frequencies $\left(|\mathrm{Z}|_{3 \mathrm{mHz}}\right.$ in the present study) could serve as an estimation of the corrosion protection of a painted metal. Fig. 3 reports $|\mathrm{Z}|_{3 \mathrm{mHz}}$ after $24 \mathrm{~h}$ of immersion in the $\mathrm{NaCl}$ solution for the four formulations with different MAPC $1(\mathrm{OH})_{2}$ contents. It can be seen that the impedance modulus is the highest for the F3 formulation (2.5\%) and decreases when the MAPC1 $(\mathrm{OH})_{2}$ concentration increases (F4 and F5). However, the decrease is not significant and the data in Fig. 2 allow a minimum efficient $\operatorname{MAPC}(\mathrm{OH})_{2}$ concentration to be determined. This concentration is around $2.5 \%$.

\subsection{Influence of the addition of new phosphonated fatty acid on the corrosion protection of coated steel}

\subsubsection{New phosphonated fatty acid}

In the present study, the phosphonation of methyl oleate was investigated. The chemical incorporation of phosphonic acid moities onto methyl oleate was done via a two-step pathway, as depicted below: 


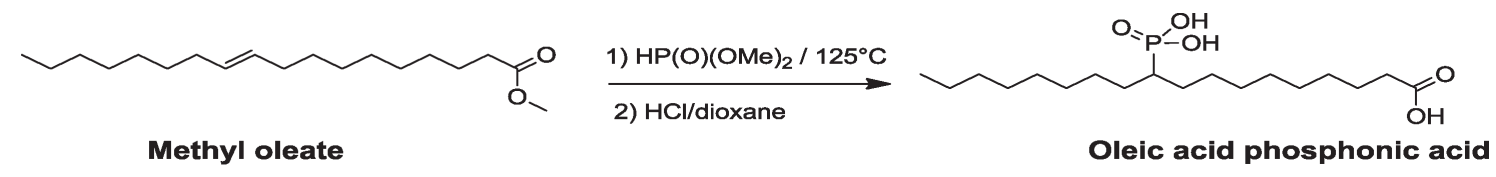

Synthesis of phosphonic acid-bearing oleic acid (phosphonated fatty acid)

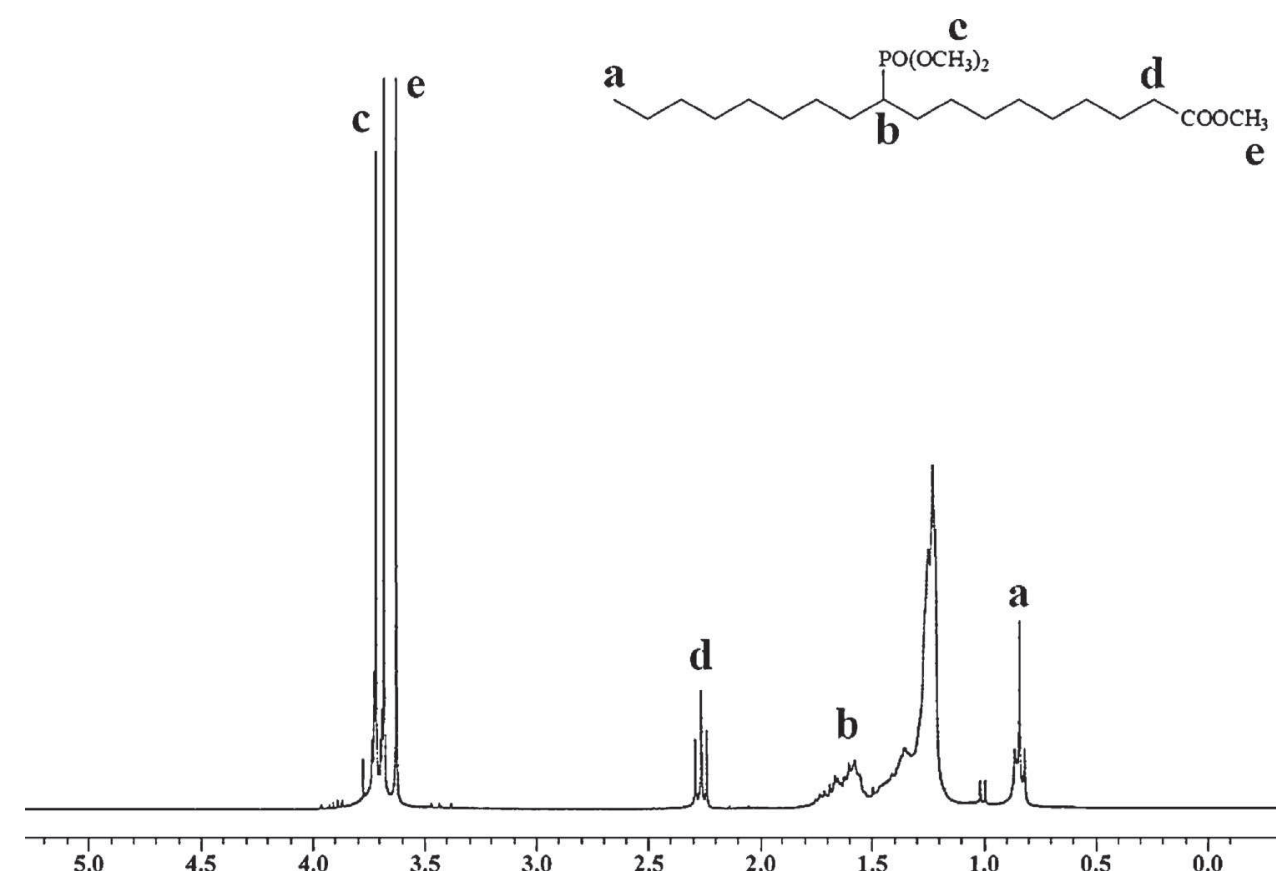

Fig. 4. ${ }^{1} \mathrm{H} \mathrm{NMR}\left(\mathrm{CDCl}_{3}\right)$ of phosphonate-bearing methyl oleate.

(a)

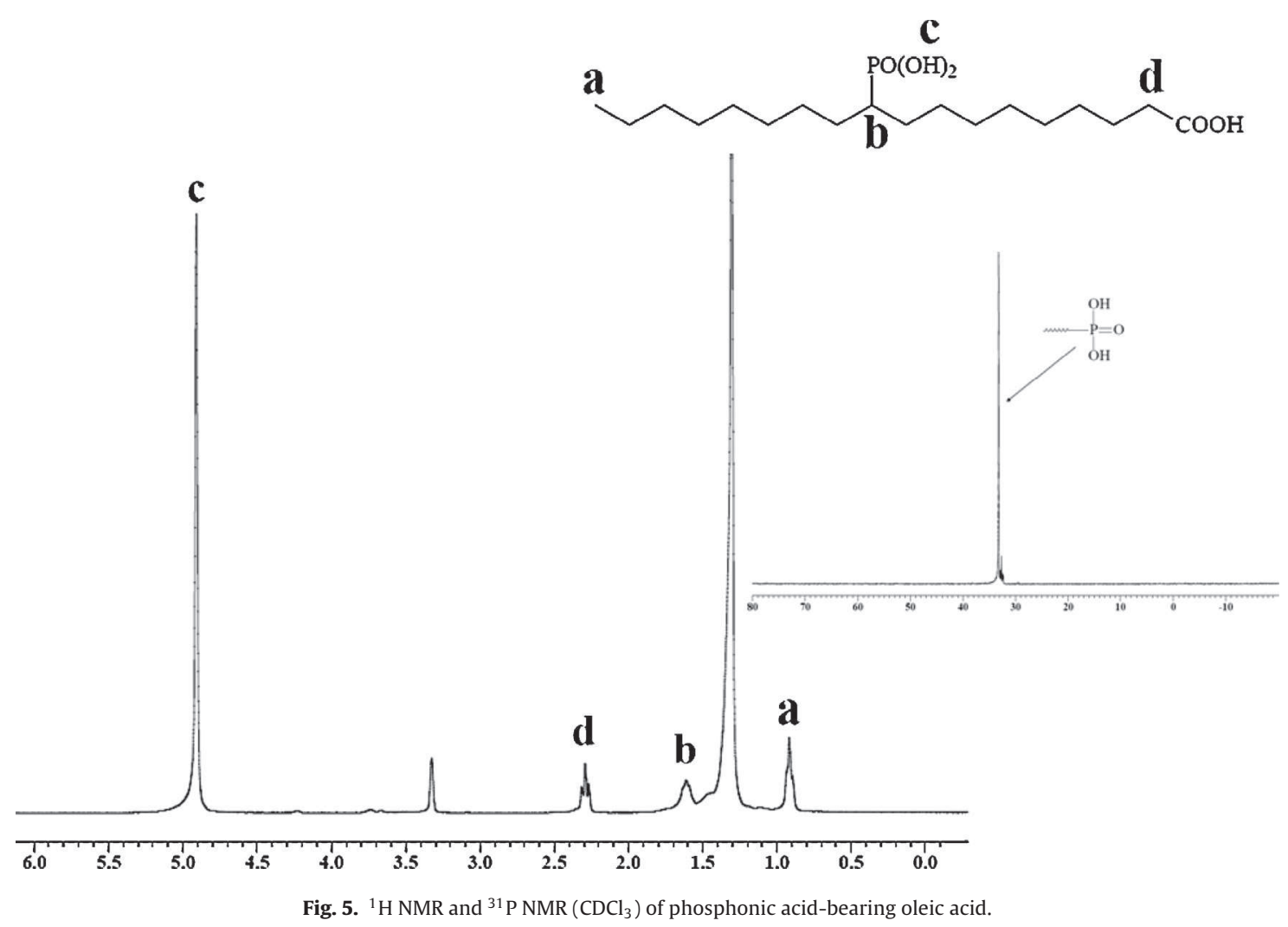




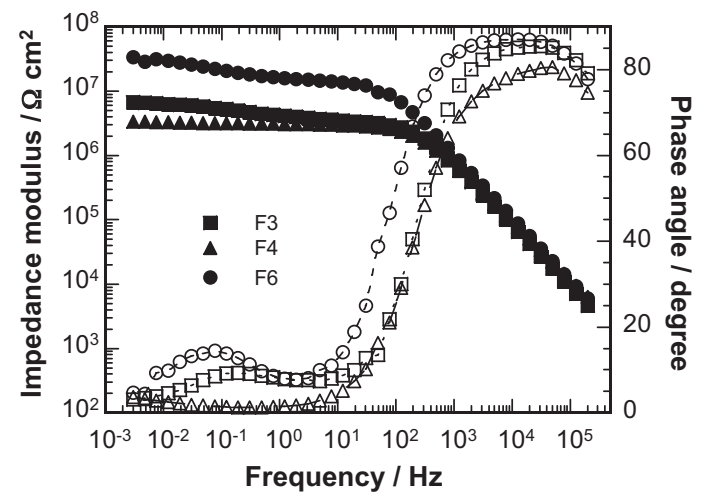

Fig. 6. Electrochemical impedance diagrams (Bode representation) obtained for samples F3, F4 and F6 after $24 \mathrm{~h}$ of immersion in $0.1 \mathrm{M} \mathrm{NaCl}$ solution.

The first step corresponds to the radical addition of dimethyl phosphite onto the unsaturated $\mathrm{C}=\mathrm{C}$ of the acid. As with thiolene radical coupling [45], radical addition of methyl oleate (MO) with dimethyl phosphite, used as chain transfer agent (CTA), was carried out at high temperature with an excess of CTA compared to double bond. In these reaction conditions, phosphonation was accomplished after $12 \mathrm{~h}$ and the resulting MO-phosphonate was obtained at about $80 \%$ yield. In Fig. $4,{ }^{1} \mathrm{H}$ NMR shows that the $\mathrm{CH}_{3}$ protons of the methylphosphonate ester appear at $3.70 \mathrm{ppm}$. Moreover, the vinyl protons of MO, centered at $5.34 \mathrm{ppm}$, are no longer present, indicating successful phosphonation. Furthermore, ${ }^{31} \mathrm{P}$ NMR showed a single peak centered at $37.7 \mathrm{ppm}$ (not reported here).

Phosphonated fatty acid was obtained in a second step by hydrolysis of methyl ester groups of phosphonate moieties with hydrochloric acid in a dioxane solution. In these reaction conditions, the methyl ester of methyl oleate was also hydrolyzed to lead to the corresponding carboxylic acid. Fig. 5 shows the ${ }^{1} \mathrm{H}$ NMR and ${ }^{31} \mathrm{P}$ NMR spectra of the phosphonated fatty acid. The $\mathrm{CH}_{3}$ protons of the methylphosphonate ester, centered at $3.70 \mathrm{ppm}$, are no longer present, indicating successful hydrolysis. In support of this, the peak of $\mathrm{P}-\mathrm{O}-\mathrm{CH}_{3}$ at $37.7 \mathrm{ppm}$ is shifted to $33.2 \mathrm{ppm}$ for $\mathrm{P}-\mathrm{OH}$.

\subsubsection{The corrosion protection of coated steel with the addition of} oleic acid phosphonic acid

It was seen that in the presence of methacrylate $\operatorname{MAPC} 1(\mathrm{OH})_{2}$, the highest impedance value was obtained when it was incorporated into the formulation at a concentration of $2.5 \%$ (F3 coating). The performance of the coating containing the phosphonated fatty acid (F6 formulation) was compared to the F3 coating. The impedance diagrams obtained after $24 \mathrm{~h}$ of immersion in the $\mathrm{NaCl}$ solution are reported in Fig. 6 . The impedance of the $\mathrm{F} 4$ coating ( $5 \%$ $\left.\operatorname{MAPC} 1(\mathrm{OH})_{2}\right)$ is also shown in order to separate the role played

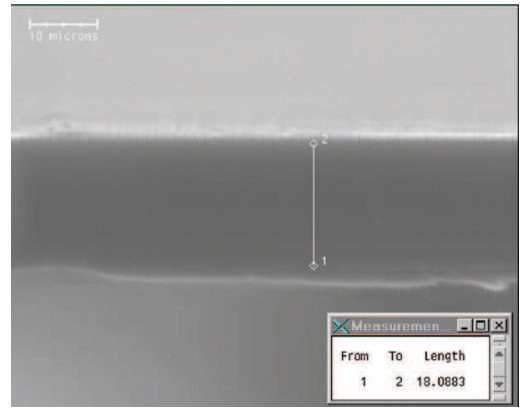

Fig. 8. SEM micrograph (cross-section) for coating F6.

by the addition of the phosphonated fatty acid and the role of the acid in the methacrylate MAPC1 $(\mathrm{OH})_{2}$. It can be seen in Fig. 6, that the addition of phosphonated fatty acid improved the barrier properties of the coating. For the F3 and F4 coatings, the impedance values in the HF range were between $2 \times 10^{6}$ and $3 \times 10^{6} \Omega \mathrm{cm}^{2}$. With the addition of the phosphonated fatty acid, the impedance value in the HF range was about ten times higher $\left(2 \times 10^{7} \Omega \mathrm{cm}^{2}\right)$. The impedance modulus at $3 \mathrm{mHz}$ was $4 \times 10^{7} \Omega \mathrm{cm}^{2}$ showing that the corrosion protection was improved.

Photographs of the electrode surface were taken at the end of the electrochemical test ( $72 \mathrm{~h}$ of immersion in the $\mathrm{NaCl}$ solution) and are shown in Fig. 7. The surface of coating F6 appears poorly corroded, and in contrast, the surfaces of the coatings F3 and F4 are damaged and corrosion products are clearly visible. The photographs corroborate the electrochemical results and underline the beneficial effect of the addition of phosphonated fatty acid on the corrosion protection of the steel surface.

To analyze the role of phosphonated fatty acid, SEM/EDX analyses were performed. The aim was to detect the phosphorus through the whole coating thickness and particularly at the metal/coating interface and to show (if possible) a phosphorus gradient concentration. For each sample two different zones were studied. Fig. 8 shows a cross-section of the F6 coating. The coating has a uniform thickness. Phosphorus profiles were obtained for F4 and F6 coatings (Fig. 9). In Fig. 9a, it can be seen that through the whole coating thickness, the quantity of phosphorus is constant. A progressive decrease can be observed at the outer part of the coating which can be explained by the SEM probe resolution. In contrast, in Fig. 9b, the phosphorus profiles are significantly modified at the metal/coating interface and reveal a higher phosphorus content. It can be seen that about $3 \mu \mathrm{m}$ of the internal zone of the coating was enriched in phosphorus. However, EDX is not a suitable technique to determine the thickness of this interfacial zone accurately. The difference between the two samples (Fig. 9a and b) was only the presence of the phosphonated fatty acid. Thus, it can be concluded that in the F6 coating the phosphonated fatty acid can migrate through the

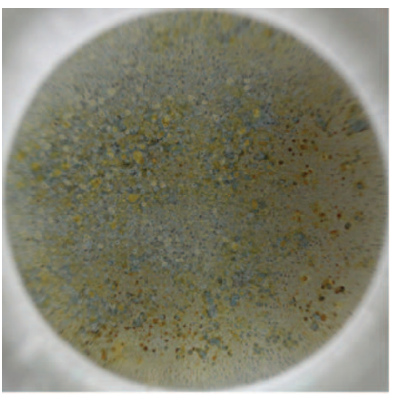

(a)

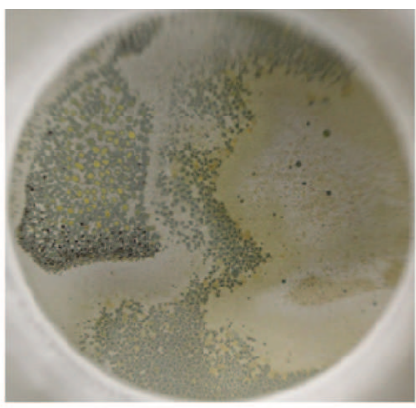

(b)

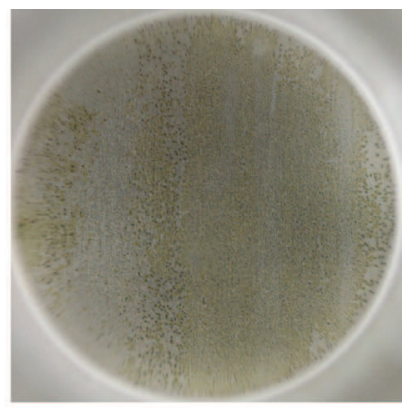

(c)

Fig. 7. Photographs of the electrode surface after $72 \mathrm{~h}$ of immersion in $0.1 \mathrm{M} \mathrm{NaCl}$ solution for samples: (a) F3, (b) F4 and (c) F6 (Surface area: $29 \mathrm{~cm}^{2}$ ). 

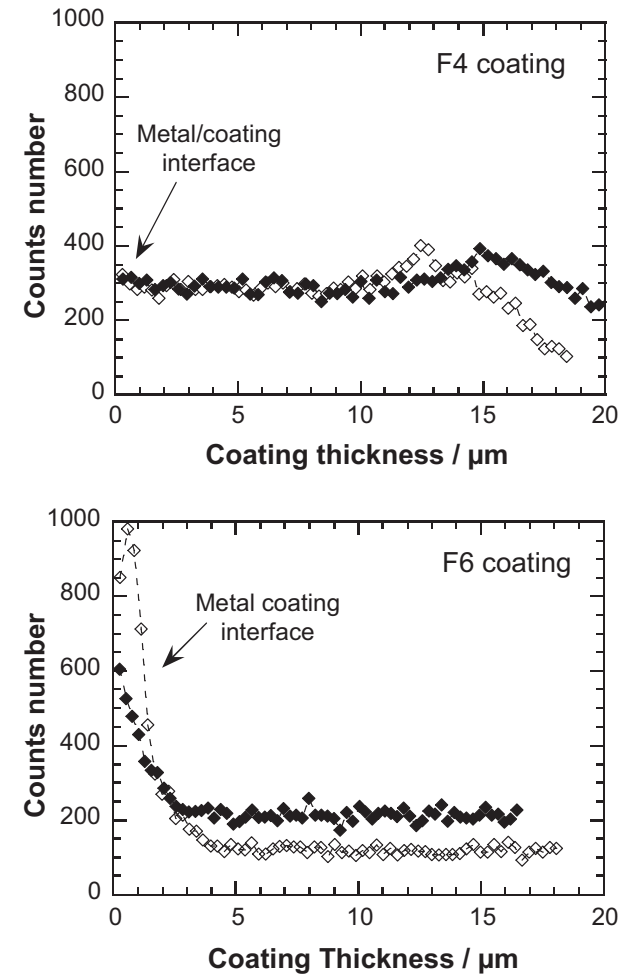

Fig. 9. Phosphorus profiles along the coating thickness for coatings F4 and F6 ( $\bullet$ : results of two independent measurements on the same sample).

film and reach the substrate to inhibit the corrosion of the steel $[46,47]$. As a consequence, corrosion resistance was improved. It can be noted that the phosphorus content was higher for the F4 coating in agreement with the higher $\operatorname{MAPC} 1(\mathrm{OH})_{2}$ content.

\section{Conclusions}

Different formulations containing diacrylate monomers, phosphonic methacrylate and a newly synthesized phosphonated fatty acid were deposited on a carbon steel substrate and polymerized by UV curing. The corrosion protection afforded by the different coatings was investigated by EIS. From the impedance data, it was found that:

(i) Phosphonic acid methacrylate provided higher corrosion resistance in comparison with ester methacrylate.

(ii) The best corrosion protection was obtained with $2.5 \%$ phosphonic acid methacrylate. An increase of the concentration did not improve the corrosion resistance of the steel.

(iii) The addition of the synthesized phosphonated fatty acid in the formulation significantly enhanced the protective properties of the coating. This performance was explained by both the barrier properties and the corrosion inhibition at the steel surface due to the presence of the phosphonic group on the molecule.

Finally, integrating phosphonated fatty acid in a bio-based coating using vegetable oils [48] seems to be promising. This study is still under investigation and should be the subject of a forthcoming publication.

\section{Acknowledgments}

The authors gratefully acknowledge Yannick Thebault for his most valuable assistance in the area of SEM-EDX. The authors also gratefully acknowledge Specific Polymers for providing the phosphonated fatty acid molecule.

\section{References}

[1] U. Quittmann, L. Lecamp, W. El Khatib, B. Youssef, C. Bunel, Macromol. Chem. Phys. 202 (2001) 628-635.

[2] K.-Y. Hwang, H.-H. Chen, A.-P. Tu, Phosphorus-Containing Resins and FireResistant Epoxy Resin Compositions Containing the Same, US Pat. Appl. Publ. U.S.A.: (Chang Chun Plastics Co., Ltd., Taiwan), 2003, 10 pp.

[3] I.Y. Wan, L.A. Keifer, J.E. McGrath, T. Kashiwagi, Polymer Preprints, Am. Chem. Soc., Div. Polym. Chem. 36 (1995) 491-492.

[4] Y. Zhang, J.C. Tebby, J.W. Wheeler, Eur. Polym. J. 35 (1998) 209-214.

[5] A.R. Horrocks, S. Zhang, Polymer 42 (2001) 8025-8033.

[6] G. Fesman, R.Y. Lin, R.A. Rehder, Flame-Retardant Mixture for Polyurethane Materials, Eur. Pat. Appl. Ep: (Stauffer Chemical Co., USA), 1985, 14 pp.

[7] J.R. Ebdon, D. Price, B.J. Hunt, P. Joseph, F. Gao, G.J. Milnes, et al., Polym. Degrad. Stab. 69 (2000) 267-277.

[8] D. Hoang, J. Kim, B.N. Jang, Polym. Degrad. Stab. 93 (2008) 2042-2047.

[9] D. Hoang, J. Kim, Polym. Degrad. Stab. 93 (2008) 36-42.

[10] S.V. Levchik, E.D. Weil, J. Fire Sci. 24 (2006) 345-364.

[11] Y.-L. Liu, G.-H. Hsiue, Y.-S. Chiu, R.-J. Jeng, L.-H. Perng, J. Appl. Polym. Sci. 61 (1996) 613-621.

[12] S.V. Levchik, E.D. Weil, Advances in Fire Retardant Materials, 2008, pp. 41-66, https://woodhead.metapress.com/content/v13w15j183wr6j2t/resourcesecured/?ta

[13] M. Zakikhani, J. Davis, Polyacrylate Phosphate Adhesive and Flame-Retardant Compositions, Eur. Pat. Appl. Ep: (Albright \& Wilson Uk Limited, UK), 1997, 10 pp.

[14] T. Okamoto, H. Mori, H. Matsuda, Adhesive Compositions, Us: (Okura Industrial Co., Japan), US, 1984, 8 pp.

[15] M. Sheffer, A. Groysman, D. Starosvetsky, N. Savchenko, D. Mandler, Corrosion Sci. 46 (2004) 2975-2985

[16] A.G. Kannan, N.R. Choudhury, N.K. Dutta, Polymer 48 (2007) 7078-7086.

[17] A.G. Kannan, N.R. Choudhury, N.K. Dutta, J. Electroanal. Chem. 641 (2010) $28-34$

[18] W. Herbst, H. Ludwig, F. Roehlitz, H. Vilcsek, Method and Material for the Application of Adhering Coatings on Iron and Steel Surfaces, De: (Metallgesellschaft A.-G.), 1965, 3 pp.

[19] N. Moszner, F. Zeuner, U.K. Fischer, V. Rheinberger, Macromol. Chem. Phys. 200 (1999) 1062-1067

[20] N. Moszner, U. Salz, J. Zimmermann, Dent. Mater. 21 (2005) 895-910.

[21] U. Salz, J. Zimmermann, F. Zeuner, N. Moszner, Polym. Preprints 45 (2004) 325-326.

[22] U. Salz, J. Zimmermann, F. Zeuner, N. Moszner, J. Adhes. Dent. 7 (2005) $107-116$.

[23] F. Zeuner, N. Moszner, T. Volkel, K. Vogel, V. Rheinberger, Phosphorus, Sulfur Silicon Relat. Elem. 144-146 (1999) 133-136.

[24] F. Zeuner, N. Moszner, M. Drache, V. Rheinberger, Phosphorus, Sulfur Silicon Relat. Elem. 177 (2002) 2263.

[25] O. Senhaji, J.J. Robin, M. Achchoubi, B. Boutevin, Macromol. Chem. Phys. 205 (2004) 1039-1050.

[26] Z. El Asri, K. Chougrani, C. Negrell-Guirao, G. David, B. Boutevin, C. Loubat, J. Polym. Sci. Part A: Polym. Chem. 46 (2008) 4794-4803.

[27] G.F. D'Alelio, Halogenated esters of phosphorus-containing acids, US Pat, Us: (USA), 1975, p. 12 pp, Continuation-in-part of U.S. 3,780,144.

[28] G.F. D'Alelio, Halogenated esters of phosphorus-containing acids, US Pat, Us: (USA), 1977, p. 11 pp, Division of U.S, 3,950,457.

[29] C.N. Smit, W.E. Hennink, B. De Ruiter, A.H. Luiken, M.P.W. Marsman, J. Bouwma, RadTech'90 North Am, Conf Proc, vol. 2, 1990, pp. 148-153.

[30] K. Chougrani, B. Boutevin, G. David, Eur. Polym. J. 44 (2008) 1771

[31] K. Chougrani, B. Boutevin, G. David, S. Seabrook, C. Loubat, J. Polym. Sci.: Polym. Chem. 46 (2008) 7972.

[32] R. Posner, P.E. Sundell, T. Bergman, P. Roose, M. Heylen, G. Grundmeier, J. Electrochem. Soc. 158 (2011) C185-C193.

[33] J.E.O. Mayne, J. Soc. Chem. Ind., Lond. 66 (1947) 93-95.

[34] L. Beaunier, I. Epelboin, J.C. Lestrade, H. Takenouti, Surf. Technol. 4 (1976) $237-254$.

[35] F. Mansfeld, M.W. Kendig, S. Tsai, Corrosion 38 (1982) 478-485.

[36] F. Mansfeld, Electrochim. Acta 35 (1990) 1533-1544.

[37] P.L. Bonora, F. Deflorian, L. Fedrizzi, Electrochim. Acta 41 (1996) $1073-1082$.

[38] K. Chougrani, B. Boutevin, G. David, S. Seabrook, C. Loubat, J. Polym. Sci. Part A: Polym. Chem. 46 (2008) 7972-7984

[39] N. Pebere, T. Picaud, M. Duprat, F. Dabosi, Corrosion Sci. 29 (1989) 1073-1086.

[40] C. Le Pen, C. Lacabanne, N. Pebere, Prog. Org. Coat. 39 (2000) 167-175.

[41] J. Kittel, N. Celati, M. Keddam, H. Takenouti, Prog. Org. Coat. 46 (2003) 135-147.

[42] G. Bierwagen, D. Tallman, J. Li, L. He, C. Jeffcoate, Prog. Org. Coat. 46 (2003) $148-157$

[43] R.L. De Rosa, D.A. Earl, G.P. Bierwagen, Corrosion Sci. 44 (2002) 1607-1620.

[44] B.R. Hinderliter, S.G. Croll, D.E. Tallman, Q. Su, G.P. Bierwagen, Electrochim. Acta 51 (2006) 4505-4515. 
[45] M. Desroches, S. Caillol, V. Lapinte, R. Auvergne, B. Boutevin, Macromolecules 44 (2011) 2489-2500.

[46] Y. Gonzalez, M.C. Lafont, N. Pebere, G. Chatainier, J. Roy, T. Bouissou, Corrosion Sci. 37 (1995) 1823-1837.
[47] Y. Gonzalez, M.C. Lafont, N. Pebere, F. Moran, J. Appl. Electrochem. 26 (1996) 1259-1265.

[48] M. Desroches, S. Caillol, R. Auvergne, B. Boutevin, G. David, Polym. Chem. 3 2012) 450-457. 